\title{
Geomechanical justification of security measures in the development of the South Khingan deposit of manganese ore
}

\author{
Maksim Rasskazov ${ }^{1 *}$, Marina Potapchuk ${ }^{1}$, Gennady Kursakin ${ }^{1}$ and Denis Tsoy ${ }^{1}$ \\ ${ }^{1}$ Mining Institute of Far Easten Branch of Russian Academy of Sciences, Khabarovsk, Russia
}

\begin{abstract}
The paper presents the results of geomechanical studies on the assessment of the potential rockburst hazard of the rock massif of the South Khingan deposit of manganese ore at the stage of development. Geodynamic zoning has been performed, mining and technical, mining and geological conditions of field development have been studied, and parameters of physical and mechanical properties of enclosing rocks and ores have been determined. Numerical simulation methods have been used to estimate the stress state of a rock massif at various stages of the deposit development. The tendency of the lower part of the South Khingan deposit to rockburst has been established. The complex of effective organizational and technical security measures has been substantiated in the development of this field. Keywords: rocks, physical and mechanical properties, stress-strain state, geomechanical justification, geodynamic zoning, development system, rockburst hazard, monitoring system.
\end{abstract}

\section{Introduction}

In the underground mining of solid mineral deposits, the prevention of mountain impacts, sudden releases of coal, rock and gas, and other dynamic phenomena are among the largest and most complex problems[1-2].

Rockbursts, representing a process of brittle fracture of the ends or edge parts of the massif, occur with a certain combination of geological and mining conditions. One of the reasons for the origin of mountain impacts is the unstable release of a part of the energy inflow, which is formed by decreasing the potential energy of the rocks around the excavations. The changes occurring in the rock massif under the influence of mining work provoke activation of the hidden focus of the seismic event, formed mainly due to the energy of deformations generated by the natural unevenness of the stress field [3-4]. It is known that the most effective solution to this problem is achieved at the design and construction stages of mining enterprises when it is possible to provide in advance a set of regional and local preventive measures that sharply reduce the danger of dynamic manifestations of rock pressure.

The object of the study is the South Khingan deposit of manganese ores located in the Oktyabrsky district of the Jewish Autonomous Region [5]. Its geodynamic position and

* Corresponding author: rasm.max@mail.ru 
confinement to tectonically active structures in the southern part of the Bureinsky middle massif at the junction of the major modern morphological elements of the region: The Middle Amur Riftogenic Depression and the Bureinsky Range, which often predetermines the deposit's inclination to rockbursts during the underground mining operations, have given rise to the geomechanical research.

\section{Mining-geological and mining-technical conditions of field development}

The main reserves of the South Khingan deposit are concentrated in the "Poperechniy" section, which is a linear ore-bearing block with a width of 40 to $80 \mathrm{~m}$ (on average - $50 \mathrm{~m}$ ) and a length of $240 \mathrm{~m}$, containing a steeply dipping ore horizon, broken by transverse and longitudinal faults into a higher-rank blocks. Ore bodies are represented by steeply dipping low-lying strata, which can be traced along the strike for hundreds of meters. The deposits are in most cases sustained, but there are crimps, bulges as well as pinches (Figure 1).

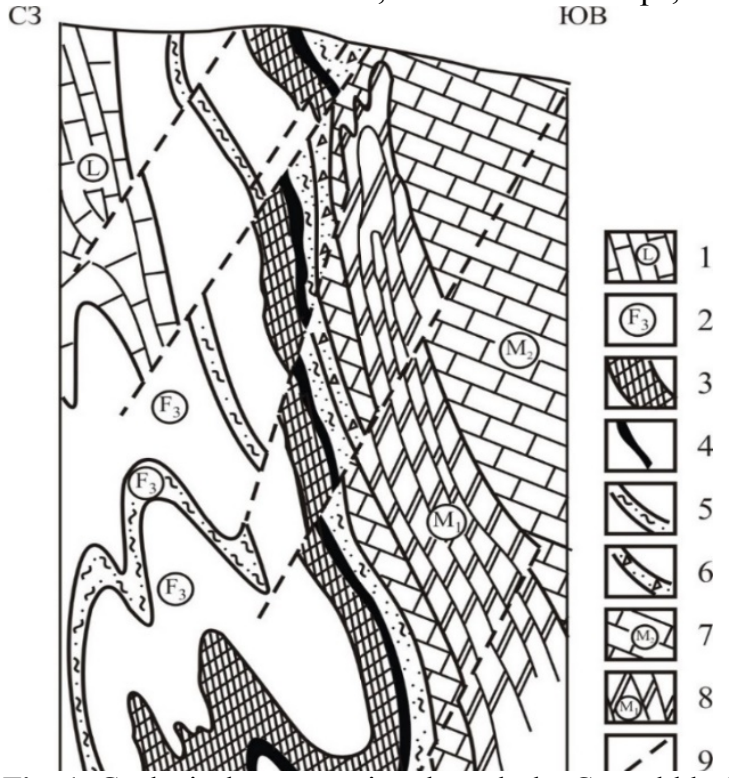

1-6 - Terrigenous-carbonate deposits of the LowerMiddle Cambrian; 7-8 terrigenous-carbonate deposits of the Upper Proterozoic - Lower Cambrian period: layered and schistous dolomites with interbeds of various shales (7); siliceous dolomites, dense dolomites (8); 9 tectonic disturbances

Fig. 1. Geological cross-section through the Central block of the "Poperechniy" section of the South Khingan deposit

The terrigenous-carbonate deposits of the Lower-Middle Cambrian period are: black limestones with clusters of carbonaceous-argillaceous and siliceous-argillaceous shales in the basement (1); clayey, carbonaceous-argillaceous and siliceous-argillaceous shales with interlayers of dolomitic sandstone (2); iron-ore layer, magnetite, magnetite-hematite microquartzites with breccia lenses (3); layered brownite-rhodochrosite-hausmanite ore (4); dolomite sandstones with siliceous-argillaceous shales (5) and sedimentary dolomite breccias (6).

The deposit is supposed to be developed by an underground method. The opening scheme provides for the penetration of two inclined trunks, the location of which is to be determined taking into account the results of the research, and coupled slopes. For the extraction of reserves, it is planned to use a development system with ore storage (with an ore body capacity of up to $3 \mathrm{~m}$ ) and systems with sub-level drifts (with an ore body capacity of 2.5-3.0 m and above), with borehole or longhole stopping. The following parameters of the development systems are provided: the length of the excavation blocks is up to $60 \mathrm{~m}$; the width of the excavation blocks is determined by the thickness of the ore 
body, but not less than $1.0 \mathrm{~m}$; the height of the excavation blocks is determined by the height of the levels and amounts to $60-70 \mathrm{~m}$. When using the development system by sublevel drifts, the excavating unit is divided into sub-stages with a height of up to $15-17 \mathrm{~m}$.

\section{Methods and results of the research}

Faults and tectonic structure of the deposit, play an important role in the formation of impact and the manifestation of technogenic seismicity $[6,7]$. Therefore, to assess the stressed state of the upper part of the lithosphere in the area of field development, its geodynamic zoning is performed, including: a complex morphostructural interpretation of different-scale topographic maps and a volumetric analysis of the modern relief of the earth's surface; target analysis of radar images (srtm30, srtm3) with the construction of appropriate neotectonic maps; generalization of information on the regional natural background of the stress-strain state of the geo-environment [11].

Calculation methods using GPS measurements and remote sensing of the earth's crust allowed for the reconstruction of the natural stress field in the region of the South Khingan deposit, which in the upper (upland) part of the massif has been formed under the action of gravitational forces, and in the lower part of the massif - from a depth of $300 \mathrm{~m}$ it is complicated by the additional action of tectonic forces. In the massif of the deep part of the deposit, the effect of an unequal component stress field is predicted, in which the horizontal compressive stresses prevail, the largest of which is oriented in the northeasterly direction and is 2.5-3 times greater than the gravitational component of the weight of the superincumbent rock [12].

The analysis of physical and mechanical properties of rocks and ores of the South Khingan deposit have shown that almost all of them (with the exception of layered and schistose dolomites) are quite strong (the strength of uniaxial compression varies from 82.3 to $174 \mathrm{MPa}$ ) and highly elastic (Young's modulus is in the range of 72.5-98.6 GPa). The results of the research show that the majority of the rocks in the "Poperechniy" section of the South Khingan deposit are those with high strength and rigidity. A negative factor is also the fact that all the rocks (F1, F2, F3) within which the cleaning dredging are planned are almost twice as strong as the surrounding M2 and L. This will contribute to a higher level of stress in the areas of the massif of mountain rocks, where the main mining works will be conducted.

Also, an unfavorable factor is the large variation in the strength and elastic parameters of the rocks within the groups, due to the diversity of their lithologic composition. For example, the increase in tensile strength is naturally correlated with the enrichment of rocks with silica (quartz and its modifications $-\mathrm{F}_{2}$ and $\mathrm{M}_{1}$ horizons), which characterizes these rocks as very fragile and capable of breaking down in a dynamic form. The brittleness index, which is the ratio of the compressive strength of rocks to the ultimate tensile strength, for all types of rocks and ores of the deposit exceeds 15.

The density of the studied section of rocks as a whole exceeds the corresponding reference characteristics of analogous metamorphosed differences. This circumstance is explained by the anomalous sulfidization of rocks of the entire section, visually observed by us when viewing the range.

Thus, the results of the studies performed give grounds to consider the rocks and ores of the South Khingan deposit as potentially dangerous.

To study the patterns of redistribution of initial stresses in a rock massif under the influence of mining operations, the finite element method (FEM) was implemented in a flat and volumetric formulation of problems $[11,12]$.

The stress-strain state of the South Khingan deposit rock massif was evaluated in two stages: first, the change in the stress-strain state (SSS) in the rock mass was studied with 
depth as the deposit was worked and the mining was reduced, and then the redistribution of stresses in the area cleaning blocks with allocation of zones of increased stresses in the elements of development systems. Based on the results of the simulation, it has been established that a complex technogenic stress field was formed during the development of the deposit. With the deepening of mining operations in individual areas of the massif, which include: non-ore areas, tectonic disturbance zones, interlevel and other pillars and marginal parts of the massif, normal and tangential stresses increase, which is especially noticeable in the lower part of the deposit. In the level $-20 \ldots-120 \mathrm{~m}$ and below (depth 300 $\mathrm{m}$ and more), the value of the first main normal stresses $\sigma_{1}$ in the entry and arch pillars when working overlying reserves exceeds $90 \mathrm{MPa}$. To assess the stresses in the structural elements of the proposed development systems (sub-level drifts and ore storage), a volumetric modeling of the stage-by-stage treatment of the cleaning unit was performed.

Analysis of the results of numerical simulation of SSS at various stages of the cleaning unit treatment showed that when the deposit was worked out by the system with sub-level drifts, the highest level of stress was noted in inter-chamber pillars, mainly in the marginal parts from the sub-level drift. As the cleaning unit is being developed, a direct proportional increase in the magnitude of the maximum compressive and tangential stresses, the magnitude of which reaches a maximum (up to $85 \mathrm{MPa}$ and $40 \mathrm{MPa}$, respectively) occurs when the unit is fully developed (Fig. 2). The complete development of the cleaning unit leads to the formation of an area of increased stresses in the central part of the overhead track on the side of the developed chamber (the main normal and tangential stresses reach 65 and $35 \mathrm{MPa}$, respectively), which increases the likelihood of dynamic manifestations of the rock pressure when it is reclaimed.

Using a system with ore stoping, the concentration of stress is observed in the interchamber ends, as well as in the marginal parts of the ore unit, even at the intermediate stage of the cleaning unit (at a stope height of $20 \mathrm{~m}$ ). An increase in the stope height leads to an increase in the first principal $\sigma 1$ and tangential stresses in the pillars by $20-25 \%$, the values of which reach $70 \mathrm{MPa}$ and $45 \mathrm{MPa}$ (Figure 3), respectively. In addition, the most loaded are the inter-chamber pillars on the side of the spent cleaning unit.

The increase in the impact hazard in the area of inter-chamber towers is predicted with the complete development of the unit (complete release of the stoped ore from the cleaning unit), when the values of the first principal $\sigma 1(85 \mathrm{MPa})$ approach the compressive strength, shear stresses $(55 \mathrm{MPa})$ to the shear strength limit. Increasing the depth of mining will increase the potential impact of these elements of the development system.

Based on the analysis of the obtained results of SSS numerical simulation and the experience of working out the deposits with similar mining geological conditions, it can be concluded that the system of sub-level drifts is less dangerous since only marginal parts of the inter-chamber pillars are loaded. The development of ore reserves using the ore shrinkage system leads to the formation of a large number of potentially rockburstdangerous ore inter-chamber pillars, which creates the conditions for dynamic manifestations of rock pressure. In general, the results of the simulation show that starting from a depth of $300 \mathrm{~m}$ (below the $-20 \mathrm{~m}$ mark), some sections of the massif (pillars, free zones, tectonic disturbance zones) are characterized by an increased stress level, which approaches the rock strength limit. This circumstance indicates the possibility of the manifestation of rock pressure in a dynamic form while working out the lower part of the South Khingan deposit. The obtained results of the research had served as the basis for its classification as prone to rockbursts and made it possible to justify and put into the project a set of measures for the prevention of dangerous geodynamic phenomena, protection and maintenance of mine workings in rockburst-prone areas. 
$a$

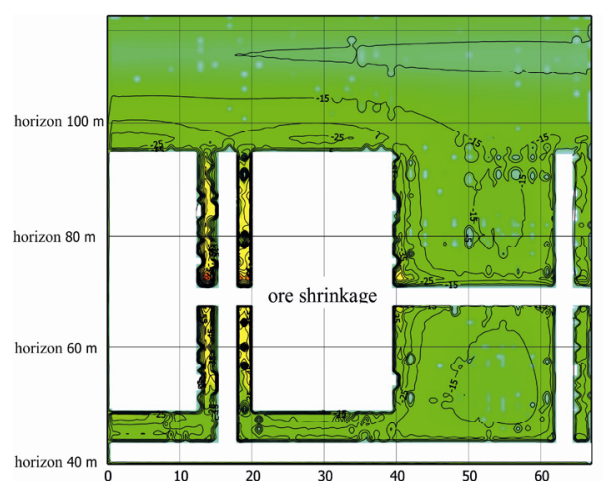

$b$

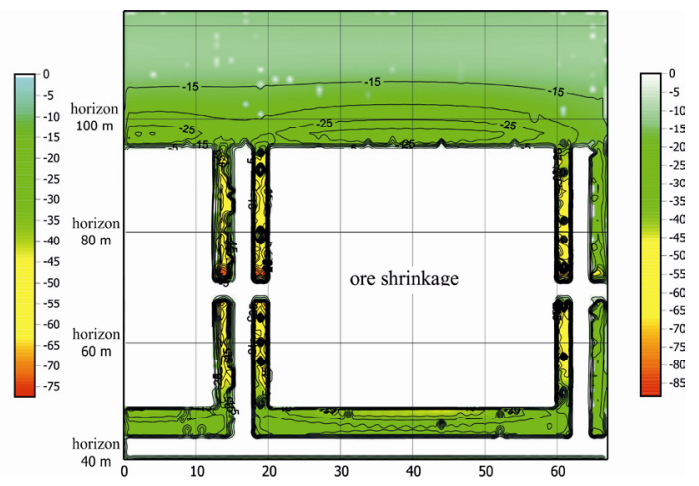

Fig. 2. Distribution of the first main stresses in the rock massif: $a$-when working out $50 \%$ of the cleaning unit; $b$ - with the complete cleaning of the cleaning unit in the level $20 \div 100 \mathrm{~m}$ a (in the projection on the inclined plane)

$a$

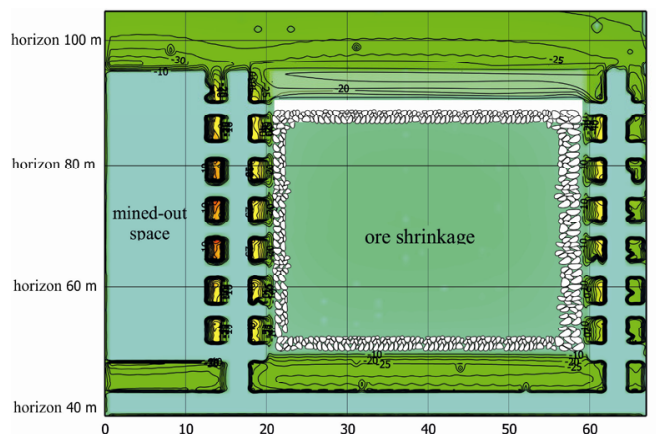

$b$

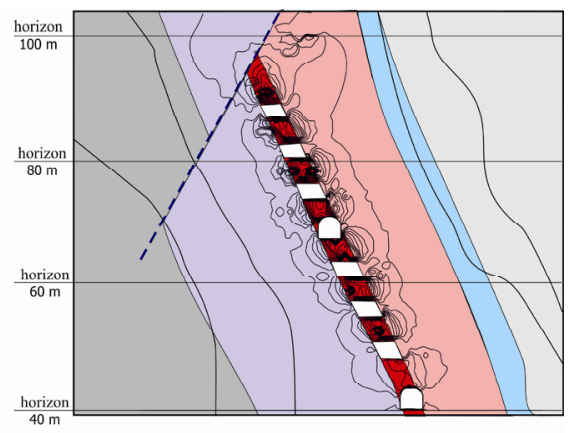

Fig. 3. Distribution of the first major stresses in the rock massif at a stope height of $40 \mathrm{~m}$ : $a$ - projection on the inclined plane; $b$ - cut into the cross of the strike of the ore body along the line of the interchamber pillar

\section{Recommendations for the Prevention of Rockbursts}

The main principle of safe mining of deposits prone to rockbursts is to ensure the order and methods of mining, in which excessive concentrations of stresses are eliminated in the rock massif and the harmful effect of rock pressure around mine workings is reduced. Mining operations should develop systematically from one flank of the field to another or from the center to the flanks, leaving the minimum number of lanes, followed by their reclamation. This principle may be implemented through the use of special preventive measures, the choice and justification of which is based on the regional and local forecast of the rockburst hazard [1, 12-13].

The results of the analysis and geomechanical justification of the South Khingan deposit made it possible to propose the following recommendations on the expediency of applying a set of the most promising organizational and technical security measures for the development of this field (Table. 2). 
Table 2. The complex of measures to prevent rockbursts

\begin{tabular}{|c|c|}
\hline $\begin{array}{l}\text { Measures to prevent } \\
\text { rockbursts }\end{array}$ & Content of measures \\
\hline Tracing of workings & $\begin{array}{l}\text { When opening and building deep horizons in tectonically tense } \\
\text { rock massifs, a mandatory preventive measure should be the } \\
\text { tracing of excavations, which contains the norm of observing } \\
\text { reasonable requirements not to place the workings production in } \\
\text { places of increased rock pressure and orient them along the } \\
\text { direction of action of the greatest main stresses. }\end{array}$ \\
\hline $\begin{array}{l}\text { Giving the polygonal } \\
\text { or elliptical shape of } \\
\text { the cross-section (or } \\
\text { face) of the working }\end{array}$ & $\begin{array}{c}\text { In the case of an unfavorable arrangement of the workings } \\
\text { (especially when oriented perpendicular to } \sigma_{\max } \text { ), it is advisable } \\
\text { to give to their cross-section a polygonal or elliptical (for } \\
\text { vertical workings) shape. }\end{array}$ \\
\hline Camouflet blasting & $\begin{array}{l}\text { When carrying out the workings in high-stressed areas of the } \\
\text { massif that are classified as "Dangerous", a protective zone } \\
\text { created by camouflage blasting or by cutting the discharge slots } \\
\text { in a plane perpendicular to } \sigma_{m a \text {. }} \text { must always be kept ahead of } \\
\text { the moving face. }\end{array}$ \\
\hline $\begin{array}{l}\text { Creating the } \\
\text { discharge slots }\end{array}$ & $\begin{array}{l}\text { With a persistent high impact hazard, it is advisable to form } \\
\text { discharge slots in the sides of the workings, oriented along the } \\
\text { direction of action } \sigma_{\max } \text {. }\end{array}$ \\
\hline $\begin{array}{c}\text { Drilling of discharge } \\
\text { wells }\end{array}$ & $\begin{array}{l}\text { When the shearing stresses are higher than the permissible } \\
\text { values, during the development of mining operations, a } \\
\text { discharge zone is created by drilling the ring of the discharge } \\
\text { wells, while orienting it if possible in a plane perpendicular to } \\
\text { the action of the maximum stresses. The angle of inclination of } \\
\text { wells in the unloading zone can be determined by the greatest } \\
\text { destruction of working. }\end{array}$ \\
\hline $\begin{array}{l}\text { "Standage" of } \\
\text { workings }\end{array}$ & $\begin{array}{c}\text { The standage of workings can be used in potentially dangerous } \\
\text { areas of the massif, only when the process of relaxation of } \\
\text { dangerous stresses in the contour zone takes a short time (not } \\
\text { more than 5-10 days). }\end{array}$ \\
\hline Fixing the workings & $\begin{array}{l}\text { The most responsible capital workings with a long service life } \\
\text { can be fixed with a constant and amenable support. }\end{array}$ \\
\hline
\end{tabular}

Along with the justification of the effective parameters of the shockproof measures, it is recommended to consider the use of special technical means for assessing the impact hazard, including the "Prognoz L" device, and "Prognoz-ADS" automatic seismoacoustic system for controlling the rock pressure and others [14].

\section{Conclusions}

1. The South Khingan deposit of manganese ores is characterized by a complex tectonic structure, its massif is composed of strong and highly elastic rocks. A large amount of silica in rocks and ores characterizes them as very fragile, capable of accumulating significant potential energy and breaking down dynamically.

2. Mathematical modeling of the stress-strain state had established its regular change with the depth of the deposit development. Starting at a depth of $300 \mathrm{~m}$, an elevated stress level is observed in some parts of the massif (interlevel pillars, uninhabited areas, tectonic disturbance zones), approaching (and in some cases exceeding) the shear strength of the 
rocks. A high potential rockburst hazard is also represented by a decreasing ore embankment under a mining development system with ore storage.

3. According to the results of geodynamic zoning, the current position of the fault zones limiting the main blocks of the site has been revealed and their position relative to the regional stress field has been shown. The obtained data are the basis for making design decisions when designing the optimal direction of horizontal excavations and the places for laying vertical ones

4. The geomechanical conditions of the South Khingan deposit and the revealed patterns of stress distribution in the elements of development systems give grounds for its attribution to those prone to rockbursts.

5. To conduct mining operations in the rockburst-prone areas of the South Khingan deposit, a set of measures to prevent dangerous manifestations of rock pressure has been justified.

\section{References}

1. I.Yu. Rasskazov, Monitoring and management of rock pressure on mines of Far East region. Mountain book. pp. 329. (2008)

2. I.M. Petukhov, P.V. Egorov, B.S. Vinokur, Preventing rockburst in mines. Nedra, (1984)

3. Cook N. G. W. Rockbursts: prediction and control. Institution of Mining and Metallurgu, pp. 1-9. (1984)

4. Salamon M. D. G. Rockbursts: prediction and control. London: Institution of Mining and Metallurgy. pp. 11-36. (1984)

5. G.I. Arkhipov, Far Eastern ferrous metallurgy: iron ore raw materials base and development opportunities. Institute of Mining of FED RAS. (2005)

6. Marcak Henryk, Mutke Grzegorz. J. Seismol. 17 (4). 1139-1148. (2013)

7. Paige E. Snelling, Laurent Godin, Stephen D. McKinnon. International Journal of Rock Mechanics and Mining Sciences. 58. 166-179. (2013)

8. V.I. Usikov. Tectonics, magmatism and geodynamics of the East of Asia: the $7^{\text {th }}$ Kosygin readings: Materials of the All-Russian Conference. - Khabarovsk city: Institute of tectonics and geophysics of FED RAS. 328-331. (2011)

9. I.Yu. Rasskazov, B.G. Saksin, M.I. Potapchuk, V.I. Usikov. Physical and technical problems of mining. 1. 13-22. (2014)

10. O.V. Zoteev. Izvestiya vuzov. Mining Magazine 5. (2003)

11. Instruction on the safe management of rocks in mines and non-ore deposits, objects of construction of underground structures, inclined and dangerous by rockbursts] State Scientific and Technical Center for Safety in Industry of the Gosgortechnadzor of Russia, (2000)

12. I.M. Petukhov, P.V. Egorov, V.Sh. Vinokur, Preventing rockburst in mines. Nedra. pp 231. (1984)

13. Control of rock pressure in tectonically tense massifs. Kolskii Scientific Center. 1. pp 159. (1996)

14. M.I. Rasskazov, P.A. Anikin, D.S. Migunov, A.A. Tereshkin, A.V. Gladyr, D.I. Tsoi, M.A. Lomov, A.S. Fedianin, E.K. Pul. Innovative trends in the design of mining enterprises: geomechanical support for the design and support of mining operations: collection of research papers of the 8th International scientific and practical conference. St. Petersburg Mining Univ. 95-101. (2017) 